\title{
Problem historii filozofii. Część pierwsza
}

DOI: http://dx.doi.org/10.12775/RF.2016.001

Zwyczajowo historia filozofii bywa przeciwstawiana filozofii jako jej gorsza połowa, jako „ubogi krewny” prawdziwej filozofii, co w konsekwencji doprowadziło do wytworzenia się osobliwej mody polegającej na nieznajomości historii filozofii, na niezawracaniu sobie głowy jej znajomością. W kontekście coraz większej tolerancji względem nieuctwa, dla niepoznaki nazywanego polityczną poprawnościa, jest to postawa w pełni usprawiedliwiona, ale nie jest to równoznaczne ze słusznością takiej postawy. Jako przykład niech posłuży książka autorstwa Juliana Younga, profesora Uniwersytetu w Auckland poświęcona Heideggerowi, w której cztery razy wymienia Brunona Baucha (1877-1942) oraz Nicolaia Hartmanna (1882-1950), zawsze razem, tak, jakby nic ich nie dzieliło. W pewnym momencie Young zdradza kompletną nieznajomość filozofii niemieckiej i pisze:

Hans Sluga wykazał, że celem tego ataku są Bruno Bauch i Nicolai Hartmann oraz inni członkowie prawicowego odłamu »Deutsche Philosophische Gesellschaft«. Bardziej jednak zastanawiające jest to, że Heidegger wiąże Nietzschego z tymi poślednimi filozofami ${ }^{1}$.

Porażający przykład nieuctwa, wpisujący się jednak doskonale w charakterystyczną dla czasów dzisiejszych pochwałę niewiedzy.

Postawa zrywająca z historią filozofii sugeruje zarazem jednoznacznie, że od zarania dziejów historię filozofii traktowano jako zbędny balast filozofii. Tymczasem nie kto inny, jak właśnie Arystoteles swoją filozoficzną wiedzę budował na doświadczeniach poprzedników, a zatem

1 J. Young, Heidegger, filozofia, nazizm, przeł. H. Szłapka, Wydawnictwo Naukowe PWN, Warszawa-Wrocław 2000, s. 206. 
jako pierwszy uznał wagę historyczności. Warto w tym miejscu przytoczyć słowa, którego autorem jest Bernard z Chartres (1060-1125):

Jesteśmy karłami, którzy wspięli się na ramiona olbrzymów. W ten sposób widzimy więcej i dalej niż oni, ale nie dlatego, ażeby wzrok nasz był bystrzejszy lub wzrost słuszniejszy, ale dlatego, że to oni dźwigają nas w górę i podnoszą o całą gigantyczną wysokość́

Jednakże w czasach nam bliższych Hegel jest tym, który przedstawiając swoją wizję relacji historii filozofii do filozofii, nie tyle przyczynił się do utrwalenia współczesnego stanowiska, ile wspierał ścisły związek filozofii z jej własną historią. Wystarczy zajrzeć do Wykładów z historii filozofii ${ }^{3}$, które to potwierdzaja, chociaż niezwykle interesujący jest Dodatek zawierający późniejszą wersję Wprowadzenia, zamieszczony w wydaniu dzieł zebranych Hegla ${ }^{4}$. Tymczasem z dzisiejszej perspektywy wydaje się raczej, że współczesny atak na historię filozofii bardzo często jest właśnie atakiem na Heglowskie rozumienie filozofii w ogóle. Atak na Hegla, który postrzegany jest jako przeciwnik filozofii naukowej, jest zarazem atakiem na jego koncepcję historii filozofii. Dziecko zostaje wylane z kąpielą. Nie idzie oczywiście o to, aby Hegla rozgrzeszać z wszystkich przewin. $W$ odniesieniu do jego filozofii pozostaje bowiem aktualne to, co stwierdził Schnädelbach, a mianowicie niemożliwość przyjęcia jej w całości, kiedy analizując problem wprowadzenia do rozumienia filozofii Hegla podkreśla: „Jeśli wszystko to się powiedzie, zapewne się przekonamy, że wprawdzie bardzo wiele możemy się od Hegla nauczyć w szczegółach, jednak w odniesieniu do całości - jaką jest filozofia - nie jest to możliwe" jest równoznaczna z odrzuceniem całego jego systemu, a to nie do końca znajduje uzasadnienie $\mathrm{w}$ odniesieniu do problemu historii filozofii.

Wydaje się, że problem postawiony jest źle i to właśnie w tym punkcie, w którym z niezrozumiałych powodów w filozofii rezygnuje się $\mathrm{z}$ historii filozofii, a nawet rezygnuje się z prób określenia wzajemnej relacji między filozofią a jej historią. Zupełnie niezrozumiała jest retoryka, zgodnie z którą historia filozofii miałaby być nauką pomocniczą filo-

2 Fragment w tłumaczeniu H. Szumańskiej-Grossowej za: T. Michałowska, Średniowiecze, wyd. 5, Wydawnictwo Naukowe PWN, Warszawa 1999, s. 17.

3 Zob. G.W.F. Hegel, Wykłady z historii filozofii, t. 1. przeł. Ś.F. Nowicki, przejrzał A. Węgrzecki, Wydawnictwo Naukowe PWN, Warszawa 1994, s. 15-166.

4 Zob. G.W.F. Hegel, Berliner Niederschrift der Einleitung. Angefangen am 24.X.1820, in: G. W. F. Hegel, Werke in 20 Bänden, Bd. 20: Vorlesungen über die Geschichte der Philosophie III, hrsg. von E. Moldenhauer, K.M. Michel, Suhrkamp Verlag, Frankfurt am Main 1970, s. 463-511.

5 H. Schnädelbach, Hegel. Wprowadzenie, przeł. A. J. Noras, Oficyna Naukowa, Warszawa 2006, s. 10. 
zofii, gdyż niejako z góry ustanawia relację nadrzędności filozofii, a co za tym idzie podrzędności historii filozofii, co niewątpliwie zaspokaja próżność niektórych „filozofów”, ale nie znajduje potwierdzenia w rzeczywistości. Można się tu doszukać analogii do samej historii, która bardzo chętnie posługuje się terminem „nauki pomocnicze historii”, przy czym termin ten jest $\mathrm{w}$ nauce historii $\mathrm{w}$ pełni uzasadniony, a analogia między historią a filozofią jest błędna.

Pojęcie nauk pomocniczych historii charakteryzuje zatem pewna względność, ogólnie zaś można powiedzieć, że dyscypliny te są związane z etapem heurezy historycznej. W konsekwencji ich pojmowanie będzie zależne od postępu różnych dziedzin nauki ${ }^{6}$.

Tymczasem historia filozofii $\mathrm{w}$ żaden sposób nie jest związana $\mathrm{z}$,etapem heurezy", a raczej ujawnia się u podstaw filozoficznej pracy, tworząc fundament filozofii i punkt wyjścia zarazem. Historia filozofii nie jest dyscypliną naukową uprawianą obok filozofii - w znaczeniu podrzędności, bo przecież filozofia z definicji jest nadrzędna - lecz stanowi istotny czynnik filozofii samej.

\section{I.}

Eo ipso historia filozofii należy do filozofii, jako jej konstytutywny element i w żaden sposób nie wyczerpuje się w rozumieniu jej jako nauki pomocniczej filozofii. Idea pomocniczności zyskuje sojusznika w koncepcji Hansa-Georga Gadamera (1900-2002), który poddając totalnej krytyce neokantyzm staje się niejako automatycznie krytykiem rozwijanej w jego ramach historii filozofii rozumianej jako historia problemów. Elementem pomijanym w ocenie koncepcji Gadamera jest właśnie to, że pod wpływem Heideggera staje się autor Prawdy $i$ metody radykalnym krytykiem neokantyzmu, a więc również rozwijanej przez niego koncepcji historii filozofii. Sformułowana przez Gadamera koncepcja historii filozofii rozumianej jako historia pojęć występuje przeciwko ujęciu neokantystów, co uwidacznia się zwłaszcza wówczas, kiedy pisze:

Gdy weźmiemy pod uwagę stanowisko przeciwne - tak zwaną historię problemów - i jego granice, rzecz cała stanie się dla nas jasna. W świetle naszych rozważań ten tradycyjny, dominujący w neokantyzmie, a więc w ciągu ostatnich 50-100 lat, sposób rozumienia dziejów filozofii okazu-

6 J. Szymański, Nauki pomocnicze historii, wyd. 6, Wydawnictwo Naukowe PWN, Warszawa 2004, s. 9. 
je się w istocie niezadowalający (nie neguję przy tym wielkich osiągnięć historii problemów) ${ }^{7}$.

Co ciekawe, Gadamer nie jest tu wnikliwym badaczem neokantyzmu, lecz powiela schemat zastosowany przez Heideggera $\mathrm{w}$ trakcie jego dysputy z Ernstem Cassirerem w Davos - w zasadzie nie zwraca się do nikogo, personalnie nie kieruje swego zarzutu wobec któregoś z neokantystów. Wspomina wprawdzie Hartmanna i Cohena, ale w odmiennym kontekście, a przy tym nie dostrzega faktu, że również twórca szkoły marburskiej miał wiele do powiedzenia w kwestii rozumienia relacji między filozofią a jej historią. Wprawdzie Nicolai Hartmann, „któremu wszyscy wiele zawdzięczamy" ${ }^{\prime \prime}$, przedstawiony jest $\mathrm{w}$ innym świetle niż Hermann Cohen, ale nie zmienia to faktu, że Gadamer daleki jest od pożądanego w badaniach naukowych obiektywizmu. Wspomina o tym sam Gadamer podkreślając, że odejście od tego, co historyczne spowodowało, iż „skończyła się dawna uczniowska zgoda z Hartmannem i poszedłem drogą Heideggera" ${ }^{\prime 9}$. To niezwykle ważny, godny podkreślenia motyw powodujący, że Gadamera sytuuje się poza neokantyzmem. Fakt, że promotorem jego doktoratu był Paul Natorp nie czyni z niego marburczyka.

Gadamer do kwestii rozumienia historii filozofii powraca w swej $A u$ tobiografii, gdzie w enigmatyczny sposób pisze:

Również neokantowska historia problemu rościła sobie prawo do rozpoznawania $\mathrm{w}$ tych problemach własnych pytań, jednakże roszczenie ponadczasowych, »odwiecznych" problemów, aby powtarzały się one w coraz to nowych związkach systemowych, nie zostało dowiedzione i w rzeczywistości owe »identyczne« problemy zaczerpnięte zostały z pełną naiwnością z tworzywa filozofii idealistycznej i neokantowskiej. [...] Dopiero gdy przy Heideggerze nauczyłem się posługiwać myśleniem historycznym, by na nowo stawiać pytania tradycji, stare pytania stały się tak zrozumiałe i żywe, iż stały się moimi własnymi ${ }^{10}$.

Enigmatyczność wypowiedzi Gadamera polega na tym, że dopuszcza się on tu pewnego uproszczenia zakładając, iż neokantowska historia problemów nie jest typem myślenia historycznego. Co więcej, w tek-

7 H.-G. Gadamer, Historia pojęć jako filozofia, przeł. K. Michalski, w: idem, Rozum, słowo, dzieje. Szkice wybrane, przeł. M. Łukasiewicz, K. Michalski, Państwowy Instytut Wydawniczy, Warszawa 2000, s. 105.

8 Ibidem.

9 H.-G. Gadamer, Moja droga do filozofii. Wspomnienia, przeł. J. Wilk, Wydawnictwo Uniwersytetu Wrocławskiego, Wrocław 2000, s. 24.

10 H.-G. Gadamer, Autobiografia, przeł. J. Wilk, w: Gadameriana. Hans-Georg Gadamer w "Zbliżeniach Polska-Niemcy. Annäherungen Polen-Deutschland”, red. K. Bal, J. Wilk, Oficyna Wydawnicza ATUT, Wrocław 2006, s. 25. 
ście Początek filozofii mówi też o ścisłym związku filozofii z jej historią w duchu neokantowskiej historii problemu i pisze:

[...] w moich wykładach poświęconych presokratykom najważniejsze i rozstrzygające jest to, że nie zaczynam ani od Talesa ani od Homera, ani też od języka greckiego w drugim tysiącleciu przed naszą erą lecz od Platona i Arystotelesa. Jest to moim zdaniem jedyna filozoficzna metoda interpretacji presokratyków. Wszystko pozostałe to historyzm, nie filozofia ${ }^{11}$.

Pokazuje zatem Gadamer, że filozoficzna metoda interpretacji dawnych myślicieli jest filozofia, co znowu w żaden sposób nie stoi w sprzeczności z ideą historii problemów.

Widać zatem wyraźnie, że Gadamer krytykuje neokantowską wizję historii filozofii rozumianej jako historia problemów za pomoca argumentów podpadających pod ową wizję. Historia filozofii rozumiana jako historia problemów filozoficznych nie jest tak daleka od Gadamerowskiej wizji dziejów, jak jemu samemu się wydaje. Historia problemów bowiem $\mathrm{w}$ ujęciu neokantystów jest zarówno myśleniem historycznym, jak również spełnia warunek ścisłego związku z filozofią. Ten drugi warunek zresztą jest nie tylko warunkiem neokantowskim, ale w sposób jednoznaczny związany jest z koncepcją Hegla. Taka sytuacja ujawnia jeszcze inny problem, a mianowicie problem obecności filozofii Hegla w neokantyzmie. Nie można bowiem zaprzeczyć temu, że Hegel jest obecny w refleksji filozoficznej neokantyzmu, aczkolwiek $\mathrm{z}$ tego powodu nie można mówić o tym, że neokantyzm jest neoheglizmem, gdyż mimo wszystko te dwa typy filozofowania zbyt wiele dzieli. Nie zmienia to jednak faktu, że w przedstawionej przez Gadamera wizji historii filozofii zawarta jest zarówno pochwała Heideggera, jak i krytyka neokantyzmu. Krytyka neokantyzmu jest jednak u Gadamera powierzchowna, nie odnosi się do konkretnych poglądów imiennie wskazanych filozofów, a więc jest w gruncie rzeczy krytyką wyobrażonej, a nie rzeczywistej wizji tej filozofii. Gadamer jednak idzie tu tropem Martina Heideggera, dla którego neokantyzm był raczej „chłopcem do bicia", niż rzeczywistym przeciwnikiem. Trzeba jednak gwoli sprawiedliwości dodać, że postawa taka ujawniła się u Heideggera z czasem, że początkowo był świadomy wagi dziedzictwa neokantyzmu ${ }^{12}$. Postawa Gadamera jest jednak tym bardziej zastanawiająca, że przecież hermeneutyka ujawnia swe historyczne zainteresowanie, a sam Gadamer w roku 1943 tak charakteryzował filozofię niemiecką:

11 H.-G. Gadamer, Poczatek filozofii, przeł. J. Gajda-Krynicka, wstęp J. Brudzińska, Wydawnictwo IFiS PAN, Warszawa 2008, s. 18.

12 Zob. M. Heidegger, Gesamtausgabe, Bd. 56/57: Zur Bestimmung der Philosophie, 2. Aufl., Vittorio Klostermann, Frankfurt am Main 1999. 
Charakterystyczną cechą ostatnich dziesięcioleci filozofii niemieckiej jest niewątpliwie nastawienie historyczne. Anglosasi uznali nawet kiedyś przewage tego nastawienia za przygniatająca, dziwiąc się dlaczego filozofia niemiecka w tak dużej mierze zajmuje się dziejami filozofii ${ }^{13}$.

Powtarzający się zwrot „nastawienie historyczne (historische Einstellung)" jest tu niezwykle ważny, gdyż po raz kolejny podkreśla związek między Gadamerowską a neokantowską wizją historii filozofii. Tym bardziej niezrozumiała wydaje się krytyka tej ostatniej przez Gadamera. Skoro trudno mówić o neokantyzmie w znaczeniu jednorodnego nurtu filozoficznego, to przecież w takim samym stopniu odnosi się to do Gadamera - trudno mówić o jednorodnej wizji historii filozofii. Na marginesie warto zaakcentować fakt, iż Anglosasi dystansują się od historii filozofii w sposób świadomy wybierając filozofię analityczną.

Stanowisko Gadamera nie jest wyjątkowe dlatego, że zawiera jakąś oryginalną koncepcję historii filozofii. Rozumienie filozofii jako historii pojęć pojawiło się już wcześniej, a mianowicie jako pierwszy przedstawił go uczeń Friedricha Adolfa Trendelenburga (1802-1872), profesor Uniwersytetu w Dorpacie Gustav Teichmüller (1832-1888), który w roku 1874 wydał pierwszą książkę ${ }^{14}$, zaś w latach 1876-1878-1879 wydał drugie, tym razem trzytomowe dzieło poświęcone temu zagadnieniu ${ }^{15}$. Już w przedmowie do pierwszego wydania zauważa, że ",[...] pierwszy warunek dla postępów filozofii stanowi historia pojęć"16. Teichmüller był nauczycielem Rudolfa Euckena (1846-1926), pierwszego filozofa laureata Literackiej Nagrody Nobla (1908) oraz Wincentego Lutosławskiego (1863-1954) ${ }^{17}$, a mimo to Stefan Swieżawski nie wspomina o nim w swym monumentalnym dziele poświęconym problemowi historii

13 H.-G. Gadamer, Problem dziejów w nowszej filozofii niemieckiej, przeł. K. Michalski. w: idem, Rozum, stowo, dzieje. Szkice wybrane..., s. 22. W oryginale czytamy: „Wenn man die Eigenart der deutschen Philosophie der letzten Jahrzehnte kennzeichnen will, so begegnet einem als ihr wichtigste Grundzug ihre historische Einstellung. Angelsächsische Beobachter haben sie gelegentlich geradezu eine erdrückend historische Einstellung genannt und sich verwundert, warum die deutsche Philosophie sich so überwiegend mit der Geschichte der Philosophie beschäftigt,.. H.-G. Gadamer, Das Problem der Geschichte in der neueren deutschen Philosophie, in: idem, Gesammelte Werke, Bd. 2: Hermeneutik: Wahrheit und Methode. Ergänzungen. Register, 2. Aufl., J. C. B. Mohr (Paul Siebeck), Tübingen 1993, s. 27.

14 G. Teichmüller, Studien zur Geschichte der Begriffe, Weidmannsche Buchhandlung, Berlin 1874.

15 G. Teichmüller, Neue Studien zur Geschichte der Begriffe, 3. Bde, Friedrich Andreas Perthes, Gotha 1876-1879.

16 G. Teichmüller, Studien zur Geschichte der Begriffe..., s. III.

17 Zob. na ten temat T. Mróz, Wincenty Lutosławski i Stefan Pawlicki. Spory i ich konsekwencje. Referat wygłoszony na posiedzeniu Komisji Historii Nauki PAU w dniu 23 czerwca 2004 r., PAU, Kraków 2004. 
filozofii ${ }^{18}$. Dodatkowo wskazać trzeba na Johanna Friedricha Herbarta (1776-1841), dla którego filozofia jest konstrukcją pojęć:

$\mathrm{K}$ a ż d a s pekula cja, bądź to teoria, system czy też co bądź, poszukuje konstrukcji pojęć, która, jeśli by$ł a b y$ kompletna, przedstawia to, co realne, tak jak ma ono za podstawę to, co się dzieje i u kazuje ${ }^{19}$.

Sytuacja Gadamera jest nie do pozazdroszczenia, gdyż w istocie trudno o oryginalną koncepcję historii filozofii właśnie $\mathrm{w}$ odniesieniu do neokantyzmu, który zagadnienie historii filozofii uczynił jednym ze swych naczelnych problemów ${ }^{20}$. W tej sytuacji autor Prawdy $i$ metody zrobił co mógł, aby wyjść poza neokantowskie ograniczenia. Gadamer uznał, że jedynym wyjściem jest hermeneutyka, która - jego zdaniem próbie naukowo uprawianej historii filozofii daje to, czego zabrakło w neokantowskich próbach. Tym brakującym elementem jest uwzględnienie kontekstu historycznego danej filozofii, co wynika z nastawienia hermeneutycznego.

Elementarne doświadczenie filozofowania cechuje to, że gdy staramy się zrozumieć klasyków myśli filozoficznej, wysuwają oni roszczenia do prawdy, których świadomość ich epoki nie potrafi ani odrzucić, ani przewyższyć. Naiwne dobre samopoczucie współczesności mogłoby się buntować przeciw temu, że świadomość filozoficzna dopuszcza możliwość, iż jej własny wgląd filozoficzny ma mniejszą rangę od wglądu Platona i Arystotelesa, Leibniza, Kanta lub Hegla. Można by upatrywać słabości współczesnego filozofowania w tym, że do interpretacji i opracowania swej klasycznej tradycji zabiera się z takim wyznaniem własnej słabości. Z pewnością jednak o wiele większa słabość myśli filozoficznej występuje wtedy, gdy ktoś nie poddaje siebie takiej próbie i woli się kompromitować. trzeba sobie powiedzieć, że przez rozumienie tekstów tych wielkich myślicieli poznana zostaje prawda nieosiągalna na innej drodze, nawet

18 S. Swieżawski, Zagadnienie historii filozofii, Państwowe Wydawnictwo Naukowe, Warszawa 1966.

19 J.F. Herbart, Allgemeine Metaphysik, nebst den Anfängen der philosophischen Naturlehre. Zweyter, systematischer Theil, August Wilhelm Unzer, Königsberg 1829, s. 5-6 (§ 163). Por. E. Cassirer, Das Erkenntnisproblem in der Philosophie und Wissenschaft der neueren Zeit, Bd. 3: Die nachkantischen Systeme, Verlag Bruno Cassirer, Berlin 1920, s. 379.

20 Zob. A. J. Noras, Philosophiegeschichte als Problem der Marburger und Südwestdeutschen Neukantianer, in: Marburg versus Südwestdeutschland. Philosophische Differenzen zwischen den beiden Hauptschulen des Neukantianismus, hrsg. von Ch. Krijnen, A.J. Noras, Königshausen \& Neumann, Würzburg 2012, s. 115-139. 
jeśli przeczy to miernikom badania i postępu, jakimi nauka mierzy sama siebie $^{21}$.

Problem Gadamera sprowadza się więc do tego, że w zasadzie jego rozumienie historii filozofii niewiele się różni od rozumienia występującego w neokantyzmie. Co więcej, Gadamer nie odbiega w sposób radykalny od sensu, jaki rozumieniu historii filozofii nadaje neokantyzm, chociaż brakiem obiektywizmu zarzucanym Gadamerowi byłoby uznanie, że jego wizja historii filozofii jest powieleniem wizji neokantowskiej. Tak się oczywiście nie dzieje, a koncepcja Gadamera właśnie dlatego zyskuje na znaczeniu, że swoją filozofię ujmuje Gadamer w tradycji hermeneutycznej, wpisując się $w$ tradycję rozumienia odmienną od neokantowskiej. Hermeneutyka zaś wnosi do rozumienia historii filozofii to, czego neokantyzm nie wniósł - chociaż nie jest to równoznaczne z faktem właściwego rozpoznania tego elementu przez Gadamera. Tym poszukiwanym elementem jest kontekst danej filozofii, która wymaga uwzględnienia coraz nowych elementów, co znalazło wyraz w koncepcji kręgu (czy też koła) hermeneutycznego, co w hermeneutyce biblijnej nosi miano "osadzenia w życiu” (Sitz im Leben). Tutaj ujawnia się dziejowość rozumienia, na którą szczególną uwagę zwracają reprezentanci hermeneutyki. W sformułowaniu potocznym powiada się, że hermeneutyka stawia sobie za zadanie zrozumieć autora lepiej, niż on sam siebie rozumiał, chociaż ujawniają się tu osobiste różnice, gdyż tak myślał Schleiermacher, ale Ricoeur już nie. Teza ta może być rozumiana tylko i wyłącznie ze względu na uwyraźniający się kontekst. „Zadanie pisze w związku z tym Gadamer - polega na tym, by na zasadzie koncentrycznych kręgów rozszerzać spójność zrozumianego sensu"22. Innymi słowy, nie dlatego badacz widzi więcej niż autor, że jest mądrzejszy od niego, ale dlatego, że wykorzystuje możliwość patrzenia w szerszym kontekście. Niemniej jednak możliwość uwzględnienia szerszego kontekstu problemowego nie jest dla Gadamera dziedzictwem neokanty$\mathrm{zmu}$, lecz wywodzi się z hermeneutyki, a filozofem ważnym $\mathrm{w}$ tym kontekście jest Dilthey.

Filozofia Hansa-Georga Gadamera wpisuje się w krytykę formalnej teorii wiedzy, którą na początku dwudziestego wieku identyfikuje się z filozofią Kanta i neokantyzmu. Wspomina o tym sam Gadamer na początku swej rozprawki Geschichtlichkeit und Wahrheit, kiedy pisze:

Istniały dwa problemy, które nas, kiedy we wczesnych latach dwudziestych dwudziestego stulecia sam włączyłem się w dyskusję filozoficzną,

21 H.-G. Gadamer, Prawda i metoda. Zarys hermeneutyki filozoficznej, przeł. B. Baran, Wydawnictwo Naukowe PWN, Warszawa 2007, s. 20-21.

22 Ibidem, s. 401. 
poruszały najbardziej. Z jednej strony był to problem świadomości historycznej wobec powszechnej ważności i ogólnej obowiązywalności prawdy. Z drugiej zaś było to pytanie o to, jak w adekwatny sposób filozof może mówić o tym, co boskie - a być może nawet: musi mówić ${ }^{3}$.

Problem świadomości historycznej jest tu niezwykle ważny dlatego, że w gruncie rzeczy odsyła do Hegla, do reprezentantów szkoły historycznej i oczywiście do hermeneutyki. Tym samym nadrzędna rola została przypisana Wilhelmowi Diltheyowi, który w sporze o rozumienie nauki wskazuje na fundamentalną opozycję „erklären - verstehen” ${ }^{24}$, a przez to cały problem zostaje sprowadzony na płaszczyznę hermeneutyczną. Gadamer ujawnia się tu nie jako neokantysta - którym nigdy w sposób świadomy nie był, a fakt, że doktorat obronił u Paula Natorpa niewiele tu zmienia - lecz jako uczeń ucznia neokantystów i zarazem wielkiego krytyka neokantyzmu, a mianowicie Heideggera.

II.

Gadamerowskie ujęcie historii filozofii z pewnością uznać należy za interesujące, niemniej jednak jedynie wpisuje się ono w dyskusję nad rozumieniem historii filozofii i jej relacji do filozofii. Jest to ważny głos, ale przecież głos występujący w chórze innych głosów. Co więcej, jak na głos filozofa poniekąd wywodzącego się ze szkoły marburskiej, nie jest to głos specjalnie oryginalny. Przecież jedynie stanowi on usprawnienie neokantowskiej koncepcji problemu, poprzez uaktualnienie go uwzględnieniem kontekstu historycznego, którego w koncepcji marburczyków zdaniem Gadamera - brakowało. W swoich analizach problemu historii filozofii Gadamer poniekąd zapomina, że neokantowskie rozumienie historii filozofii wpisuje się w sięgającą Kanta tradycję dyskutowania nad rozumieniem historii filozofii. Ponieważ rzecz dotyczy całej tradycji filozofii zachodniej, warto odwołać się tylko do dwóch tradycji. Wprawdzie może tu tu pojawić posądzenie o arbitralność, ale jedynym argumentem świadczącym o tym, że tak nie jest pozostaje argument formalny i przekonanie, że wystarczy odwołać się do przedstawicieli dwóch wielkich tradycji myśli zachodniej.

23 H.-G. Gadamer, Historyczność i prawda, przeł. A. Przyłębski, w: A. Przyłębski, Gadamer, Wiedza Powszechna, Warszawa 2006, s. 174.

$24 \mathrm{Na}$ temat hermeneutyki w kontekście metodologicznym zob. K. Wuchterl, Methoden der Gegenwartsphilosophie, Verlag Paul Haupt, Bern-Stuttgart 1977; J. GajdaKrynicka, Hermeneutyka jako metodologia nauk humanistycznych, w: Prawda a metoda, cz. 2: O prawdzie, red. J. Jaskóła, A. Olejarczyk, Wydawnictwo Uniwersytetu Wrocławskiego, Wrocław 2006, s. 211-224. 
Wilhelm Dilthey problem historii filozofii uznaje za jeden z najważniejszych, a uwagi dotyczące rozumienia historii filozofii zbiera w tekście Próby [zmierzajace do] wykrycia struktury historii filozofii ${ }^{25}$. Rozumienie historii filozofii wiąże się u Diltheya z naczelnym przesłaniem jego filozofii, jakim jest teoria światopoglądów, która jest jedną z pierwszych prób wyprowadzenia filozofii z impasu, w jakim znalazła się pod wpływem Hegla. Co więcej, a będzie jeszcze o tym mowa, nie ma żadnych przeciwskazań, aby filozofię w dziewiętnastym wieku postrzegać właśnie w kontekście spajających ją klamr, jakimi są bez wątpienia filozofie Hegla i Dilthey. Z kolei Paul Ricoeur (1913-2005) podejmuje problem w tekście opublikowanym w języku polskim stosunkowo wcześnie ${ }^{26}$, chociaż problem ten pojawia się też później, kiedy na przykład mówi $\mathrm{o}$ „krytycznej filozofii historii" ${ }^{27}$. Ricoeur wychodzi z założenia, że historia filozofii zawiera się między dwoma biegunami, które tworzą z jednej strony system, z drugiej - osobliwość danej filozofii.

Oba te »typy « lektury podlegają swoistym ograniczeniom. Z jednej strony trudno jest dotrzeć do pełnego systemu; być może nawet u Hegla nie wszystko jest systemem. Tak samo trudno jest dotrzeć do osobliwości; historyk zawsze zatrzymuje się na rozumieniu pośrednim, występującym na poziomie pewnych wspólnych rodzajów, nie docierając wcale do osobliwej esencji ${ }^{28}$.

Dilthey też mówi o tym, że historia filozofii rozumiana bywa na dwa sposoby, przy czym zauważa:

[...] recepcja tej masy szczątków w opracowaniu historycznym przybrała tylko dwie postacie: postać przedstawien doksograficznych według tematów filozofii i przyrodoznawstwa, jak też według zawartych w nich problemów. Obok tego wystąpiły przedstawienia życia i teorii poszczególnych filozofów czy też systemów teoretycznych poszczególnych szkół ${ }^{29}$.

Już to wystarczy do sformułowania paradygmatu, pod jaki podpadać powinna historia filozofii, paradygmatu, który wynika z krzyżujące-

25 W. Dilthey, Próby [zmierzające do] wykrycia struktury historii filozofii, w: idem, O istocie filozofii i inne pisma, przeł. E. Paczkowska-Łagowska, Państwowe Wydawnictwo Naukowe, Warszawa 1987, s. 179-204.

26 P. Ricoeur, Historyczność a historia filozofii, przeł. S. Cichowicz, w: Drogi wspótczesnej filozofii, red. M. J. Siemek, Czytelnik, Warszawa 1978, s. 243-263.

27 P. Ricoeur, Krytyczna filozofia historii, w: idem, Pamięć, historia, zapomnienie. przeł. J. Margański, Towarzystwo Autorów i Wydawców Prac Naukowych UNIVERSITAS, Kraków 2007, s. 395-457.

28 P. Ricoeur, Historyczność a historia filozofii..., s. 245-246.

29 W. Dilthey, Próby [zmierzające do] wykrycia struktury historii filozofii..., s. 180. 
go się podziału dokonanego przez Ricoeura i Diltheya. Historia filozofii powinna być historią problemów ujętych w system.

Ta ze wszech miar słuszna diagnoza w odniesieniu do historii filozofii ma tylko jeden słaby punkt; jest nim realizacja tak sformułowanego programu. Przede wszystkim dlatego, że samo pojęcie systemu jest niejednoznaczne i odsyła $\mathrm{w}$ pierwszym rzędzie do Hegla, ale właśnie na dwie kwestie należy tu zwrócić uwagę, a mianowicie na fakt, że system rozumiany tu jest $w$ świetle filozofii idealistów niemieckich - Fichte, Schelling a zwłaszcza Hegel - oraz to, że Heglowskie rozumienie systemu nie wytrzymało próby czasu i z kolei ono samo wymaga stosownych korekt $^{30}$. Niezwykle interesująca jest w tym względzie uwaga Tomasza Komendzińskiego, który przedstawia rozumienie systemu w koncepcji Charlesa Sandersa Peirce'a (1839-1914):

System filozofii nie jest odpowiednikiem systemu filozoficznego. Pierwsze pojęcie dotyczy każdej koncepcji filozoficznej, bowiem każda posiada pewną strukturę (nie zawsze świadomie kształtowaną przez autora). System filozoficzny zaś jest zazwyczaj świadomym formułowaniem spójnej koncepcji w obszarze wszystkich dyscyplin filozoficznych. Charakteryzuje go więc dążenie do spójności oraz pełności ${ }^{31}$.

Kłopoty z realizacją sformułowanego programu pojawiają się również dlatego, że ujęcie problemu jest niejednoznaczne, na co zwracał już uwagę Gadamer, chociaż nie ustrzegł się w tym wypadku braku obiektywizmu. Jest to widoczne zwłaszcza wtedy, gdy - co już zaznaczono podkreśla, że

[...] roszczenie ponadczasowych, »odwiecznych« problemów, aby powtarzały się one w coraz to nowych związkach systemowych, nie zostało dowiedzione i w rzeczywistości owe »identyczne« problemy zaczerpnięte zostały z pełną naiwnością z tworzywa filozofii idealistycznej i neokantowskiej ${ }^{32}$.

Tymczasem zagadkowe jest właśnie to, z jakich powodów Gadamer kwestionuje odwieczny charakter problemów. Przecież nie idzie o to, że te same problemy powracają $\mathrm{w}$ tej samej szacie. Pytanie zresztą brzmi, czy rzeczywiście mogłyby wrócić w tej samej szacie? Pojęcie problemu

30 Zob. na ten temat Ch. Krijnen, Philosophie als System. Prinzipientheoretische Untersuchungen zum Systemgedanken bei Hegel, im Neukantianismus und in der Gegenwartsphilosophie, Königshausen \& Neumann, Würzburg 2008.

31 T. Komendziński, Znak i jego ciagłość. Semiotyka C. S. Peirce'a między precepcja i recepcja, Wydawnictwo UMK, Torun 1996, s. 8 (przypis); zob. A.J. Noras, Kant a neokantyzm badeński i marburski, Wydawnictwo Uniwersytetu Śląskiego, Katowice 2000, s. $117-118$.

32 H.-G. Gadamer, Autobiografia..., s. 25. 
musi być rozumiane bardzo szeroko, a mowa o tym, że problem powraca nie oznacza przecież, że filozofowie (historycy filozofii) do znudzenia powtarzają te same tezy. „To raczej - pisze Nicolai Hartmann - same problemy mają historyczną ciągłość" ${ }^{\prime \prime 3}$. Dziwne, że nie zauważył tego jego uczeń, Hans-Georg Gadamer.

Teza, że w filozofii nieustannie powracają te same problemy, nie jest niczym innym, jak podkreśleniem kontekstowości filozofii, która z kolei wynika z historyczności problematyki filozoficznej. Problem jest ten sam, ale przecież pojawia się $\mathrm{w}$ zupełnie innym kontekście historycznym, przy całkowicie odmiennym stanie nauki i jego swoistość polega na odniesieniu do innego kontekstu historycznego. Nawet jeśli założyć, że problem jest jeden, to przecież wielość kontekstów i zmienność odczytań powoduje, iż można mówić o wielości problemów. Absurdem byłoby poszukiwanie w pismach Immanuela Kanta odpowiedzi na pytanie nurtujące Ernsta Cassirera, wybitnego neokantysty, ucznia Hermanna Cohena, dotyczące relacji między filozofią a nauką w kontekście, który jest właściwy nauce w czasach Cassirera. A przecież Kanta też interesował problem relacji między filozofią a nauka, chociaż stawiał go $\mathrm{w}$ zupełnie innym świetle, a ponadto - co po raz kolejny trzeba tu podkreślić - jest Cassirer wybitnym neokantystą. Ktoś, kto nie dostrzega odmienności ujęcia problemu ze względu na diametralnie różny stan nauki, nie wie, o czym mówią ci, z którymi polemizuje Gadamer. W 1786 roku Kant opublikował dzieło Metaphysische Anfangsgründe der Naturwissenschaft ${ }^{34}$, w którym odnosi się do Isaaca Newtona i jego rozumienia nauki. Byłoby jednak niedorzecznością gdyby Ernst Cassirer publikując 124 lata później książkę poświęconą zagadnieniu nauki odwoływał się także do Newtona, w ogóle nie wziąwszy pod uwagę faktu rozwoju nauki. Tym bardziej, że w roku 1905 Albert Einstein ogłosił szczególna, zaś w 1915 roku ogólną teorię względności. Co więcej, nonsensem byłoby, gdyby Cassirer w ogóle nie uwzględnił filozoficznych osiągnięć swoich nauczycieli. Konsekwencją jest książka Substancja i funkcja (Substanzbegriff und Funktionsbegriff) ${ }^{35}$, która stanowi niemal sztandarowy przykład tego, co oznacza historia filozofii rozumiana jako historia problemów filozoficznych. Ktoś, kto czytałby książkę Cassirera jako dzieło neokantowskie, nie znając historycznego tła neokantyzmu,

33 N. Hartmann, Myśl filozoficzna $i$ jej historia, w: idem, Myśl filozoficzna i jej historia. Systematyczna autoprezentacja, przeł. J. Garewicz, Wydawnictwo Comer, Torun 1994, s. 16.

34 I. Kant, Metaphysische Anfangsgründe der Naturwissenschaft, in: idem, Gesammelte Schriften, Bd. 4: Kritik der reinen Vernunft (1. Aufl.), Prolegomena, Grundlegung zur Metaphysik der Sitten, Metaphysische Anfangsgründe der Naturwissenschaft, Georg Reimer, Berlin 1911, s. 465-565.

35 E. Cassirer, Substancja i funkcja. Badania nad podstawowymi problemami krytyki poznania. przeł. P. Parszutowicz, Wydawnictwo Marek Derewiecki, Kęty 2008. 
miałby ogromne trudności ze znalezieniem wspólnego mianownika łączącego dzieła Cassirera i Kanta. Z tej perspektywy zupełnie niezrozumiała jest uwaga Gadamera, który stwierdza: „Zawsze identyczny problem jest jak nigdy rzeczywiście nie zadane pytanie"36. Tyle tylko, że należałoby zapytać: dlaczego identyczny, skoro problem zmienia się wraz z kontekstem tak, jak zmienia się pojęcie? Zwróciła na to uwage Barbara Skarga, która pytała: „Czy nie jest raczej tak, że wciąż zmianie ulega płaszczyzna rozwiązań, osiągając jakby inny teoretyczny poziom i powodując głębokie przekształcenia w strukturach sensu, a co za tym idzie, przeformułowanie starych problemów?"37. Właśnie idzie o to, aby zmienność zawartości problemu uznać za rzecz naturalną, uznając jednocześnie, że problemy są takie same. Skoro w poznaniu, a więc również $\mathrm{w}$ filozofii, dokonuje się postęp, to jest oczywiste, że ten sam problem występuje w zmienionej postaci, chociaż dalej jest tym samym problemem. Problem ugruntowania filozofii jest problemem znalezienia punktu wyjścia i racji dla filozofii, niezależnie od tego, czy ugruntowanie to dokonuje się w koncepcji Platona, czy też Hermanna Cohena. Jest czymś oczywistym, że ugruntowanie filozofii Platon rozumie zupełnie inaczej niż Hermann Cohen, ale nie zmienia to faktu, że dalej jest to problem ugruntowania. Problem ugruntowania występuje więc $\mathrm{w}$ innej postaci u Platona, zaś w innej postaci u Cohena - ale mimo to nie przestaje być problemem ugruntowania filozofii.

Warto przy tej okazji odwołać się do postaci Wilhelma Windelbanda, współtwórcy badeńskiej szkoły neokantyzmu, który odegrał bardzo ważną rolę $\mathrm{w}$ rozumieniu historii filozofii jako historii problemów, publikując w roku 1892 swe najbardziej znane dzieło zatytułowane Geschichte der Philosophie ${ }^{38}$, które od trzeciego wydania nosiło bardziej znany dziś tytuł Lehrbuch der Geschichte der Philosophie $e^{39}$. Nieco wcześniej, bo w roku 1883 Windelband wydał po raz pierwszy zbiór swoich rozpraw i przemówień i w przedmowie do tego zbioru zapisał znamienne słowa, które na całe lata określiły metodologiczne dążenia neokantystów i to nie tylko tych ze środowiska heidelberskiego. Windelband pisze:

36 H.-G. Gadamer, Historia pojęć jako filozofia..., s. 107.

37 B. Skarga, Złudzenia i nadzieje historyka filozofii, w: eadem, Przeszłość i interpretacje. $Z$ warsztatu historyka filozofii, Państwowe Wydawnictwo Naukowe, Warszawa 1987, s. 46-48. Pisze o tym również wnikliwie M. Tyl, Filozofia - historia - historia filozofii. Filozoficzne konteksty polskiej historiografii filozofii XX wieku, Wydawnictwo Uniwersytetu Śląskiego, Katowice 2012, s. 361-362.

38 W. Windelband, Geschichte der Philosophie, J. C. B. Mohr (Paul Siebeck), Freiburg im Breisgau 1892.

39 Zob. W. Windelband, Lehrbuch der Geschichte der Philosophie, 3. Aufl., J. C. B. Mohr (Paul Siebeck), Tübingen-Leipzig 1903. 
My wszyscy, którzy filozofujemy w dziewiętnastym wieku, jesteśmy uczniami Kanta. Ale nasz dzisiejszy »powrót« do niego nie powinien być tylko odnowieniem historycznie uwarunkowanej postaci, $\mathrm{w}$ jakiej przedstawił on ideę filozofii krytycznej. Im mocniej ujmuje się antagonizm, jaki ujawnia się między różnymi motywami jego myślenia, tym bardziej znajduje się tam środki do opracowania problemów, które stworzył on swoimi rozwiązaniami problemów. Zrozumieć Kanta oznacza wykroczyć poza niego ${ }^{40}$.

Windelband dostrzega więc konieczność uprawiania innego rodzaju filozofii (i historii filozofii zarazem). Skoro zrozumieć oznacza przekroczyć, to trudno mówić o tym, że historyk filozofii jest tym, który jedynie „zdaje sprawę". A skoro nie może „wykroczyć poza” i „przekroczyć kogoś” zupełnie dowolnie, to musi być tym, który wie, poza kogo wykracza. Innymi słowy - co w zasadzie zdaje się budzić zdziwienie tylko filozofów historyk filozofii musi być filozofem.

III.

Wilhelm Dilthey, który w swoich rozważaniach podejmował kwestię rozumienia filozofii, był przekonany, że problem relacji między historią filozofii a filozofią można rozwiązać w ten sposób, że historię filozofii wyniesie się do poziomu nauki. Tak rozumiana historia filozofii „jest [...] dziełem XIX wieku. Zrodziła się ze współdziałania niemieckiej filozofii transcendentalnej z rozwojem świadomości historycznej i krytyki literackiej" ${ }^{41}$. Warto uwyraźnić stanowisko Diltheya, który podkreśla konieczność uwzględnienia trzech elementów, a na pierwszym miejscu pojawia się filozofia transcendentalna. Dilthey wskazuje przy tym na wzrost świadomości historycznej, który można wiązać z Heglem oraz znaczenie krytyki literackiej mające swe źródła w hermeneutyce. Powszechnie wiadomo, że sam Dilthey był jednym z rzeczników hermeneutyki, a jedną z pierwszych książek było dzieło poświęcone twórcy hermeneutyki, Friedrichowi Ernstowi Danielowi Schleiermacherowi (1768-1834) ${ }^{42}$. Książka była sygnowana jako tom pierwszy, ale tom drugi nie ukazał się za życia autora.

Dilthey wskazuje więc trzy filary naukowej historii filozofii, którymi personalnie są Kant, Hegel i Schleiermacher. Jest to ważne również

40 W. Windelband, Vorwort, in: idem, Präludien Aufsätze und Reden zur Einführung in die Philosophie, Bd. 1., 4. Aufl., J.C.B. Mohr (Paul Siebeck), Tübingen 1911, s. IV. Szerzej zob. A.J. Noras, Historia neokantyzmu, Wydawnictwo Uniwersytetu Śląskiego, Katowice 2012, s. 462-478.

41 W. Dilthey, Próby [zmierzajace do] wykrycia struktury historii filozofii..., s. 180.

42 W. Dilthey, Leben Schleiermachers, Bd. 1, Georg Reimer, Berlin 1870. 
dlatego, że tym samym pozostaje w sprzeczności z Gadamerem, który wprawdzie dostrzega wagę Hegla i Schleiermachera - aczkolwiek hermeneutykę postrzega przez pryzmat Heideggera - to jednak nie zauważa wkładu Kanta, a przez to neokantyzmu. Powodów, dla których Dilthey odgrywa niewątpliwie ważną rolę $w$ rozumieniu filozofii jest wiele, ale należałoby zwrócić uwagę przynajmniej na ten jeden. W odniesieniu do Hegla Herbert Schnädelbach zauważa:

Hegel, co zrozumiałe samo przez się, żywił jeszcze tradycyjne wyobrażenie, które pielęgnowali wszyscy filozofowie przed nim, a mianowicie, że istnieje tylko jedna filozofia, że »ta« filozofia do nikogo nie należy i że można wymienić najwyżej pojedynczych filozofów, którzy przyczynili się do budowy gmachu filozofiii ${ }^{43}$.

Gdyby założyć, że teza ta decyduje o rozumieniu filozofii na początku dziewiętnastego wieku, to jego zwieńczenie stanowi przekonanie Diltheya, że wprawdzie filozofii jest wiele. ale się one nie wykluczają tylko uzupełniają. Znalazło to wyraz w pojęciu świadomości historycznej, co $\mathrm{w}$ konsekwencji doprowadziło go do tezy o komplementarnym charakterze filozofii. Systemy filozoficzne się uzupełniaja, a nie wykluczają. Zatem uznać trzeba, że w dziewiętnastym stuleciu filozofia zatoczyła koło, które symbolicznie można nazwać kołem biegnącym od Hegla do Diltheya. Hegel wierzył w istnienie jednej filozofii, a Dilthey po zawirowaniach wiarę tę przywrócił. Było to jednak możliwe, że Dilthey inaczej niż Gadamer, nie rezygnuje z możliwości uprawiania filozofii jako filozofii problemów. Oczywiście, że z jednej strony akcentuje znaczenie światopoglądowej strony filozofii, ale z drugiej strony już u Wilhelma Gottlieba Tennemanna (1761-1819) dostrzega dążenie do naukowego charakteru historii filozofii. „W tym sensie uczeń Kanta, Tennemann, zastosował $\mathrm{w}$ dążeniu do naukowości $\mathrm{w}$ historii filozofii ideę stopniowego rozwoju rozumu; $\mathrm{w}$ ten sposób dała się ona doskonale pogodzić z założeniem odnalezionego w końcu jedynie prawdziwego systemu" ${ }^{\prime 4}$.

Idea "stopniowego rozwoju rozumu" jest ta, która w pełni odpowiada projektowi Diltheya i w tym sensie jest w pełni zgodna z postulatem, jaki stawiać można względem naukowo rozumianej historii filozofii. Idea ta ma jednak jedną wadę, chociaż niekoniecznie jest ona immanentnie zawarta w niej samej. Rzecz w tym, że najczęściej wiąże się ona z przekonaniem, że rozwój jest ciągły. Tymczasem wydaje się, że pojęcie ciągłego rozwoju nie jest właściwe dla oceny tego, z czym mamy do czynienia nie tylko w filozofii, lecz także w całej humanistyce. Można mówić o postępie dopiero wtedy, kiedy oceniając sytuację ex post zauwa-

43 H. Schnädelbach, Hegel. Wprowadzenie..., s. 3.

44 W. Dilthey, Próby [zmierzajace do] wykrycia struktury historii filozofii..., s. 185. 
ża się rzeczywisty postęp. Jednocześnie bardzo często wygląda to tak, że postęp jest wątpliwy. Leszek Kołakowski w swych analizach historycznofilozoficznych odwoływał się do kategorii „wielkiego filozofa”, aczkolwiek nieobecność tej kategorii w czasach mu współczesnych tłumaczył w sposób następujący: „W historii idei kategoria »wielkiego filozofa « jest najoczywiściej zbędna, i o tyle, o ile tradycyjna historia filozofii ustępuje miejsca historii idei tak pojętej, również »wielki filozof « usuwa się ze sceny, którą historyk opisuje"45. Skoro jednak „wielki filozof" ma być kategorią nadrzędną, to rozwój nie może być rozumiany jako ciągły.

IV.

Herbert Schnädelbach analizując rozumienie historii filozofii zanotował:

W filozofii zatem alternatywą dla tego, co historyczne, nie jest już to, co czysto racjonalne - filozofowanie $\mathrm{z}$ »czystego« rozumu - lecz to, co dialogiczne. Dialog ustaje, jeśli ktoś ciągle tylko mówi »ja albo »my«; jest to czysta autoprezentacja bądź propaganda. Jednakże bez mówienia »ja « też nie ma dialogu. Jak bowiem można porozmawiać z kimś, kto nieustannie mówi tylko o czymś, nie ujawniając tego, co sam przy tym myśli? Jeszcze gorzej, gdy taki mówca mówi o kimś - np. o mnie - ale nie do mnie, tzn. bez zwracania się do mnie przez »ty« lub »pan«. Wynika stąd następujący wniosek: Wprowadzenie do filozofii historycznej także musi być historyczne, musi być zatem sprawozdawczą prezentacją jej podstaw i wiernie przedstawić fakty; zarazem jednak będzie w miarę filozoficzne, jeśli uda mu się przemówić do czytelnika i wyrobić w nim przekonanie, że jest ważne dla naszego współczesnego filozofowania. Filozofie historyczne nie są osobliwościami, które można archiwizować, opisywać i w jakiś sposób »klasyfikować«; zgodnie z własnym sensem, są one głosami $\mathrm{w}$ wielogłosowym dyskursie, który nazywamy »filozofią«; chcą być przez nas wysłuchane i wzywają nas do zajęcia stanowiska. Jedynie $\mathrm{w}$ dialogicznym obcowaniu $\mathrm{z}$ myśleniem historycznym można osiagnąć połączenie tego, co filozoficzne, z tym, co historyczne - połączenie, dla którego po historyzmie nie ma alternatywnego rozwiązania ${ }^{46}$.

Stąd wynika, jak się zdaje, kilka ważnych postulatów, które musi uwzględnić filozoficzna historia filozofii, skoro chce spełnić warunek naukowości.

Przede wszystkim historia filozofii chcąca spełnić warunek naukowości inna się oczywiście odcinać od wszelkich

45 L. Kołakowski, "Wielki filozof" jako kategoria historyczna, w: idem, Pochwała niekonsekwencji. Pisma rozproszone z lat 1955-1968, t. 1, Niezależna Oficyna Wydawnicza, Warszawa 1989, s. 200.

${ }^{46}$ H. Schnädelbach, Hegel. Wprowadzenie..., s. 8. 
faktograficznych ujęć filozofii, które koncentrują się tylko na elementach doksograficznych, pomijajac to co najistotniejsze - problemy filoz o f i c z n e. Na tej podstawie Mieczysław Gogacz odrzuca takie koncepcje filozofii, jak koncepcja pozytywistyczna, intuicjonistyczna, fragmentarystyczna, kulturowa oraz erudycyjno-pozytywizująca ${ }^{47}$.

Po drugie, powinna się wystrzegać jakichkolwiek śladów stronniczości, wynikającej z przyjęcia określonej wizji filozofii. Symptomatycznym przykładem takiego stanowiska jest założenie szkoły lubelskiej, że kryzys filozofii wiąże się bezwzględnie z nazwiskiem Kanta. Wprawdzie nie podlega żadnej dyskusji fakt, że Kant przeformułował problem metafizyki, ale nie jest to jednoznaczne ze stwierdzeniem, że metafizykę zniszczył. Dyskusja na ten temat toczy się wśród zwolenników i przeciwników Kanta, ale nawet w gronie tych pierwszych nie ma jednomyślności w ocenie dokonań autora Krytyki czystego rozumu. Tymczasem - nie deprecjonując oczywiście osiągnięć szkoły lubelskiej - nikt nie ma wątpliwości, że w jej ramach nie chodzi o jakąś metafizykę, lecz o metafizykę realistyczną.

Po trzecie, co wiąże się bezpośrednio z powyższym, h i s t o r y k filozofii znajduje się poniekąd w sytuacji etyka o c e n i a jąc e g o lu d z ki c z y n. Zadaje on, czy też nie zadaje sobie pytania: co jest istotne $\mathrm{w}$ analizowanej filozofii? I na tak postawione pytanie odpowiada w pierwszym rzędzie: intencja. Zatem również w odniesieniu do historyka filozofii ważne jest poznanie zamiaru, z jakim analizowany filozof podejmuje określony problem. Ta kwestia jest zresztą najbardziej dyskusyjna, gdyż ujawnia się tu zarzewie konfliktu: czy poznanie intencji, stoi w sprzeczności z pożądanym dystansem?

Po czwarte, jedynie w wyjątkowych sytuacjach historyk filozofii musi zwrócić uwagę na przesłanki biograficzne, które w decydujący sposób w pływają na rozumienie filozofii. Przykładem jest tu biografia Sørena Kierkegaarda (1813-1855), wychowywanego w obsesyjnej atmosferze religijnej, co zaowocowało pesymistycznym spojrzeniem na rzeczywistość. Wprawdzie pesymizm jest dziedzictwem epoki, gdyż w radykalnej metafizycznej odmianie wprowadził go dopiero Artur Schopenhauer (1788-1860) i rozwinął jego epigon Eduard von Hartmann (1842-1906), ale w najbardziej znaczącym stopniu określił właśnie filozofowanie tego, który uchodzi za ojca egzystencjalizmu. Nie w każdym jednak wypadku biografia jest tak istotna.

47 Zob. M. Gogacz, W sprawie koncepcji historii filozofii, "Zeszyty Naukowe KUL" 1964, t. 7, z. 3, s. 53. 
Po piąte, jeśli historia filozofii ma być historią problemów ujętych w system, to mowa może być tylko o tzw. systemi e otwarty m, zakładając, iż problem historii filozofii (a więc również filozofii) jest problemem o charakterze nieskończonym. Z tego powodu Paul Natorp w swej analizie marburskiej koncepcji poznania odnosi się do „filozofii rozumianej jako metoda nieskończonego, twórczego rozwoju” ${ }^{48}$.

Poszóste, pojawia się tu problem komplementarności badań historycznofilozoficznych, na który zwracał uwage - co nie dziwi w kontekście poprzedniego postulatu polski marburczyk Władysław Tatarkiewicz. Pisząc na temat interwencjonizmu w historii filozofii zauważa: "Z interwencjonizmu nie wynika, by historia musiała być subiektywna: wynika natomiast, że musi, jak zresztą każda nauka, być wysiłkiem zbiorowym, że tylko stopniowo zbliżać się może do celu, że interwencja interwencję uzupełnia" ${ }^{49}$. Wydaje się, że wymagana komplementarność jest ostatecznie dowodem tego, że filozofia (resp. historia filozofii) nigdy się nie skończy.

\section{Bibliografia}

Cassirer E., Das Erkenntnisproblem in der Philosophie und Wissenschaft der neueren Zeit, Bd. 3: Die nachkantischen Systeme, Verlag Bruno Cassirer, Berlin 1920.

Cassirer E., Substancja i funkcja. Badania nad podstawowymi problemami krytyki poznania. przeł. P. Parszutowicz, Wydawnictwo Marek Derewiecki, Kęty 2008.

Dilthey W., Leben Schleiermachers, Bd. 1, Georg Reimer, Berlin 1870.

Dilthey W., Próby [zmierzajace do] wykrycia struktury historii filozofii, w: idem, O istocie filozofii i inne pisma, przeł. E. Paczkowska-Łagowska, Państwowe Wydawnictwo Naukowe, Warszawa 1987, s. 179-204.

Gadamer H.-G., Autobiografia, przeł. J. Wilk, w: Gadameriana. Hans-Georg Gadamer w "Zbliżeniach Polska-Niemcy. Annäherungen Polen-Deutschland", red. K. Bal, J. Wilk, Oficyna Wydawnicza ATUT, Wrocław 2006.

Gadamer H.-G., Das Problem der Geschichte in der neueren deutschen Philosophie, in: idem, Gesammelte Werke, Bd. 2: Hermeneutik: Wahrheit und Methode. Ergänzungen. Register, 2. Aufl., J. C. B. Mohr (Paul Siebeck), Tübingen 1993.

48 P. Natorp, Kant a szkoła marburska, przeł. A. J. Noras, w: Neokantyzm badeński i marburski. Antologia tekstów, red. A. J. Noras, T. Kubalica, Wydawnictwo Uniwersytetu Śląskiego, Katowice 2011, s. 247.

49 W. Tatarkiewicz, O pisaniu historii filozofii, w: idem, Droga do filozofii i inne rozprawy filozoficzne, t. 1, Państwowe Wydawnictwo Naukowe, Warszawa 1971, s. 74. 
Gadamer H.-G., Historia pojęć jako filozofia, przeł. K. Michalski, w: idem, Rozum, słowo, dzieje. Szkice wybrane, przeł. M. Łukasiewicz, K. Michalski, Państwowy Instytut Wydawniczy, Warszawa 2000.

Gadamer H.-G., Historyczność i prawda, przeł. A. Przyłębski. w: A. Przyłębski, Gadamer, Wiedza Powszechna, Warszawa 2006.

Gadamer H.-G., Moja droga do filozofii. Wspomnienia, przeł. J. Wilk, Wydawnictwo Uniwersytetu Wrocławskiego, Wrocław 2000.

Gadamer H.-G., Początek filozofii, przeł. J. Gajda-Krynicka, Wstęp J. Brudzińska, Wydawnictwo IFiS PAN, Warszawa 2008.

Gadamer H.-G., Prawda i metoda. Zarys hermeneutyki filozoficznej. przeł. B. Baran, Wydawnictwo Naukowe PWN, Warszawa 2007.

Gadamer H.-G., Problem dziejów w nowszej filozofii niemieckiej, przeł. K. Michalski. w: idem, Rozum, stowo, dzieje. Szkice wybrane....

Gajda-Krynicka J., Hermeneutyka jako metodologia nauk humanistycznych. w: Prawda a metoda, cz. 2: O prawdzie, red. J. Jaskóła, A. Olejarczyk, Wydawnictwo Uniwersytetu Wrocławskiego, Wrocław 2006, s. 211-224.

Gogacz M., W sprawie koncepcji historii filozofii, "Zeszyty Naukowe KUL" 1964, t. 7, z. 3, s. 53.

Hartmann N., Myśl filozoficzna i jej historia, w: idem, Myśl filozoficzna i jej historia. Systematyczna autoprezentacja, przeł. J. Garewicz, Wydawnictwo Comer, Toruń 1994.

Hegel G. W. F., Berliner Niederschrift der Einleitung. Angefangen am 24.X.1820, in: idem, Werke in 20 Bänden, Bd. 20: Vorlesungen über die Geschichte der Philosophie III, hrsg. von E. Moldenhauer, K.M. Michel, Suhrkamp Verlag, Frankfurt am Main 1970, s. 463-511.

Hegel G. W. F., Wykłady z historii filozofii, t. 1. przeł. Ś.F. Nowicki, przejrzał A. Węgrzecki, Wydawnictwo Naukowe PWN, Warszawa 1994.

Heidegger M., Gesamtausgabe, Bd. 56/57: Zur Bestimmung der Philosophie, 2. Aufl., Vittorio Klostermann, Frankfurt am Main 1999.

Herbart J. F., Allgemeine Metaphysik, nebst den Anfüngen der philosophischen Naturlehre. Zweyter, systematischer Theil, August Wilhelm Unzer, Königsberg 1829.

Kant I., Metaphysische Anfangsgründe der Naturwissenschaft, in: idem, Gesammelte Schriften, Bd. 4: Kritik der reinen Vernunft (1. Aufl.), Prolegomena, Grundlegung zur Metaphysik der Sitten, Metaphysische Anfangsgründe der Naturwissenschaft, Georg Reimer, Berlin 1911, s. 465-565.

Kołakowski L., "Wielki filozof” jako kategoria historyczna, w: idem, Pochwała niekonsekwencji. Pisma rozproszone z lat 1955-1968, t. 1, Niezależna Oficyna Wydawnicza, Warszawa 1989.

Komendziński T., Znak i jego ciagłość. Semiotyka C. S. Peirce'a między precepcja i recepcja, Wydawnictwo UMK, Torun 1996.

Krijnen Ch., Philosophie als System. Prinzipientheoretische Untersuchungen zum Systemgedanken bei Hegel, im Neukantianismus und in der Gegenwartsphilosophie, Königshausen \& Neumann, Würzburg 2008.

Michałowska T., Średniowiecze, wyd. 5, Wydawnictwo Naukowe PWN, Warszawa 1999. 
Mróz T., Wincenty Lutosławski i Stefan Pawlicki. Spory i ich konsekwencje. Referat wygłoszony na posiedzeniu Komisji Historii Nauki PAU w dniu 23 czerwca 2004 r., PAU, Kraków 2004.

Natorp P., Kant a szkoła marburska, przeł. A. J. Noras, w: Neokantyzm badeński i marburski. Antologia tekstów, red. A. J. Noras, T. Kubalica, Wydawnictwo Uniwersytetu Śląskiego, Katowice 2011, s. 247.

Noras A. J., Historia neokantyzmu, Wydawnictwo Uniwersytetu Śląskiego, Katowice 2012.

Noras A. J., Kant a neokantyzm badeński i marburski, Wydawnictwo Uniwersytetu Śląskiego, Katowice 2000.

Noras A. J., Philosophiegeschichte als Problem der Marburger und Südwestdeutschen Neukantianer, in: Marburg versus Südwestdeutschland. Philosophische Differenzen zwischen den beiden Hauptschulen des Neukantianismus, hrsg. von Ch. Krijnen, A. J. Noras, Königshausen \& Neumann, Würzburg 2012, s. 115-139.

Ricoeur P., Historyczność a historia filozofii, przeł. S. Cichowicz, w: Drogi współczesnej filozofii, red. M. J. Siemek, Czytelnik, Warszawa 1978, s. 243$-263$.

Ricoeur P., Krytyczna filozofia historii, w: idem, Pamięć, historia, zapomnienie. przeł. J. Margański, Towarzystwo Autorów i Wydawców Prac Naukowych UNIVERSITAS, Kraków 2007, s. 395-457.

Schnädelbach H., Hegel. Wprowadzenie, przeł. A. J. Noras, Oficyna Naukowa, Warszawa 2006.

Skarga B., Złudzenia i nadzieje historyka filozofii, w: Eadem, Przeszłość i interpretacje. Z warsztatu historyka filozofii, Państwowe Wydawnictwo Naukowe, Warszawa 1987.

Swieżawski S., Zagadnienie historii filozofii, Państwowe Wydawnictwo Naukowe, Warszawa 1966.

Szymański J., Nauki pomocnicze historii, wyd. 6, Wydawnictwo Naukowe PWN, Warszawa 2004.

Tatarkiewicz W., O pisaniu historii filozofii, w: idem, Droga do filozofii i inne rozprawy filozoficzne, t. 1, Państwowe Wydawnictwo Naukowe, Warszawa 1971.

Teichmüller G., Neue Studien zur Geschichte der Begriffe, 3. Bde, Friedrich Andreas Perthes, Gotha 1876-1879.

Teichmüller G., Studien zur Geschichte der Begriffe, Weidmannsche Buchhandlung, Berlin 1874.

Tyl M., Filozofia - historia - historia filozofii. Filozoficzne konteksty polskiej historiografii filozofii XX wieku, Wydawnictwo Uniwersytetu Śląskiego, Katowice 2012.

Young J., Heidegger, filozofia, nazizm, przeł. H. Szłapka, Wydawnictwo Naukowe PWN, Warszawa-Wrocław 2000.

Windelband W., Geschichte der Philosophie, J. C. B. Mohr (Paul Siebeck), Freiburg im Breisgau 1892.

Windelband W., Lehrbuch der Geschichte der Philosophie, 3. Aufl., J. C. B. Mohr (Paul Siebeck), Tübingen-Leipzig 1903. 
Windelband W., Vorwort, in: idem, Präludien Aufsätze und Reden zur Einführung in die Philosophie, Bd. 1., 4. Aufl., J. C. B. Mohr (Paul Siebeck), Tübingen 1911.

Wuchterl K., Methoden der Gegenwartsphilosophie, Verlag Paul Haupt, Bern-Stuttgart 1977.

\section{Problem historii filozofii}

\section{Słowa kluczowe}

Kistoria filozofii, historia pojęć, historia idei, historia problemów, Hans-Georg Gadamer, Nicolai Hartmann.

Relacja między filozofią a jej historią stanowi istotny element refleksji filozoficznej w neokantyzmie szkoły badeńskiej i szkoły marburskiej. Związany z duchem szkoły, choć do niej nienależący Hans-Georg Gadamer podejmuje - w imię faworyzowanej przez siebie historii pojęć - dyskusję z rozumieniem historii filozofii jako historii problemów filozoficznych. Paradoks polega na tym, i na tym też koncentruje się artykuł, że historia pojęć nie jest wcale tak odległa od krytykowanej przez Gadamera historii problemów. Co więcej, okazuje się, że sama historia pojęć ma również długą historię, gdyż należu do niej zaliczyć takich myślicieli, jak Gustav Teichmüller czy też jeszcze wcześniej Johann Friedrich Herbart rozumiejący historię filozofii jako konstrukcję pojęć.

\section{The problem of the history of philosophy}

\section{Keyword}

History of philosophy, history of concepts, history of ideas, history of problems, Hans-Georg Gadamer, Nicolai Hartmann

Relation between philosophy and its history is an important element of philosophical reflection in both Baden and Marburg school of neo-Kantianism. Associated with the spirit of the school although not a member of it Hans-Georg Gadamer starts, in the name of his favored history of concepts, a discussion with understanding of philosophy as a history of philosophical problems. The paradox is, and that is the focus of this article, that history of concepts is not that far from history of problems criticized by Gadamer. Moreover it turns out that history of problems itself has a long history as well, as it should include a philosophers like Gustav Teichmüller or even earlier Johan Friedrich Herbart who understood philosophy as a construction of concepts. 